\title{
ESTIMATION OF HEAVY METALS IN LITTLE BLUE HERON (Egretta caerulea) COLLECTED FROM SEPETIBA BAY, RIO DE JANEIRO, BRAZIL
}

\author{
Aldo Pacheco Ferreira \\ Escola Nacional de Saúde Pública Sérgio Arouca \\ Centro de Estudos da Saúde do Trabalhador e Ecologia Humana (CESTEH/ENSP/FIOCRUZ) \\ (Rua Leopoldo Bulhões, 1480, 21041-210 Manguinhos, Rio de Janeiro, RJ, Brasil)
}

\begin{abstract}
A B S TRACT
Samples of liver and kidney of Little Blue Heron (Egretta caerulea) collected on Sepetiba Bay, Rio de Janeiro, Brazil, were analysed for their copper, zinc, cadmium, lead, chromium and nickel content. Mean concentration levels in liver and kidney ( $\mu \mathrm{g} \cdot \mathrm{g}^{-1}$ dry weight) were 6.32955 and $6.57136(\mathrm{Cd})$; 78.17409 and $96.89409(\mathrm{Zn}) ; 44.01727$ and $65.20864(\mathrm{Cu}) ; 41.15091$ and $39.62318(\mathrm{~Pb}) ; 2.80091$ and $4.16455(\mathrm{Cr})$; and 9.27182 and $9.91091(\mathrm{Ni})$, respectively. Results indicate relatively high trace metal contamination in E. caerulea, showing potential widespread biological and mutagenic adverse effects at trophic levels, and therefore, signalling risk to human health.
\end{abstract}

\section{RESUMO}

Amostras de fígado e rim de Garça-azul pequena (Egretta caerulea) coletadas na Baía de Sepetiba, Rio de Janeiro, Brasil, foram analisadas quanto às concentrações-traço de cobre, zinco, cádmio, chumbo, cromo e níquel. Os níveis médios de concentração no fígado e no rim ( $\mu \mathrm{g} \cdot \mathrm{g}^{-1}$ de peso seco) foram 6,32955 e 6,57136 (Cd); 78,17409 e 96,89409 (Zn); 44,01727 e 65,20864 (Cu); 41,15091 e $39,62318(\mathrm{~Pb}) ; 2,80091$ e 4,16455 (Cr) e 9,27182 e 9,91091 (Ni), respectivamente. Estes resultados indicam contaminação relativamente alta de metais traço em $E$. caerulea, evidenciando potencial poder de generalização adversa de efeitos biológicos e mutagênicos em níveis tróficos, e, por conseguinte sinalizando risco para a saúde humana.

Descriptors: Heavy metal, Contamination, Sepetiba Bay, Egretta caerulea.

Descritores: Metais pesados, Contaminação, Baía de Sepetiba, Egretta caerulea.

\section{INTRODUCTION}

Sea birds gather considerable levels of trace elements due to their position in marine food webs and their long lifespan. Cadmium $(\mathrm{Cd})$, which is often naturally present in the environment, is toxic to marine biota. Essential elements, such as copper $(\mathrm{Cu})$, nickel (Ni) and zinc $(\mathrm{Zn})$, are necessary for metabolism but can cause adverse effects when their concentrations in the organism become excessive. Quantification of trace element levels in different tissues of the organism is an indicator of the bioavailable fraction of the element in the environment (JOHANSEN et al., 2006).

The pollution of aquatic systems is due not only to natural causes but also and principally to anthropogenic activity such as leads to the discharge of domestic or industrial effluents, the leaching of the soil and the runoff of pesticides in agricultural areas, among others (AMADO-FILHO et al., 1999). The nature of metals from both natural and anthropogenic sources combined with their use in biological processes results in a multifaceted system for assessment. The distribution of metals in abiotic and biotic systems should be examined so as precisely to evaluate their impact on ecosystems. Wildlife studies of exposure and effect can be challenging, but the results are more complete than evaluation of metal concentrations alone. Birds are good sentinel species because they are observable, sensitive to toxicants, and live in different trophic positions. Consequently, studies assessing avian population status, reproductive success, and toxicological importance of metal exposures can be extrapolated to other wildlife and probably humans.

Pollution in the marine environment has become an issue of great concern, especially to coastal states (PEREIRA; EBECKEN, 2009). The oceans cannot provide an infinite sink for anthropogenic wastes but little attention has been paid to evaluating the limits of the capacity of coastal areas for waste assimilation (JURESA; BLANUSA, 2003). Knowledge of the ocean and of the impact of human activities on it can reveal the complexity and interdependence of all aspects of the system (COSTANZA; FARLEY, 2007). Improved acquaintance with these and better forecasting ability are required for more effective and sustained development of the marine environment to 
obtain associated economic benefits and to preserve marine resources (JURESA; BLANUSA, 2003). Recent concerns about the connectivity of ocean health issues and their relationship to human disease highlight an important area for study (FERREIRA, 2009; PEREIRA; EBECKEN, 2009).

The aquatic environment - with its associated water quality - is considered the main factor determining the state of health and disease in both man and animals (WALSH, 1990). Nowadays, the increasing use of the waste chemical and agricultural drainage systems represents the most dangerous chemical pollution (KAREZ et al., 1994; LACERDA; MOLISANI, 2006). In some cases the concentrations of certain metals in marine waters have reached levels which cause damage to wildlife populations and create serious human health problems. Identifying levels in wildlife which have been raised as a result of pollution is difficult, since very few data have been reported concerning the natural levels of metals in any species of marine vertebrates (STORELLI et al., 2007).

Egretta caerulea (Linnaeus, 1758) is a heron that occurs in temperate and tropical America, with wide distribution in Brazil. As it is a very abundant species at the study site, it was chosen as an indicator for this project, thus corroborating other studies along the same line (COSSON et al., 1988; BURGER; GOCHFELD, 1993; BONCOMPAGNI et al., 2003; TOMAN et al., 2005).

The purpose of this project was to evaluate selected metal concentrations in various tissues of $E$. caerulea collected from Sepetiba Bay, which is situated on the southern Atlantic Coast of the State of Rio de Janeiro, Brazil (Fig. 1). This area constitutes an important natural breeding ground for molluscs, crustaceans, fish, and in the Coroa Grande mangrove swamp, many species of seabird, E. caerulea being particularly highly abundant (AMADO-FILHO et al., 1999; DITTMAR et al., 2006). However, several environmental problems have been brought to the Bay, due to poor sanitary conditions, including domestic and industrial sewage effluents, increasing the threat of damage to health particularly that related to the bioaccumulation of heavy metals at trophic levels (COPELAND et al., 2003; LACERDA; MOLISANI, 2006), which was the main reason for the authors' undertaking this present study.

\section{Material ANd Methods}

We analysed twenty-two adult specimens found stranded or dead in Coroa Grande mangrove swamp, Sepetiba Bay, State of Rio de Janeiro, between March 2007 and December 2008. After collection the birds were brought to the laboratory, and their carcasses were immediately necropsied in accordance with JAUNIAUX et al. (1998), while putrescent specimens were discarded. Organs (liver, kidney) were culled, weighed, and maintained at $20^{\circ} \mathrm{C}$ for later analysis.

In the laboratory, two identical samples of approximately $100 \mathrm{mg}$ each were prepared from liver and kidney. One of the samples of each tissue was kept for toxicological analysis and the other was ovendried at $60^{\circ} \mathrm{C}$ until a constant weight was reached to allow the measurement of the concentrations of the various elements.

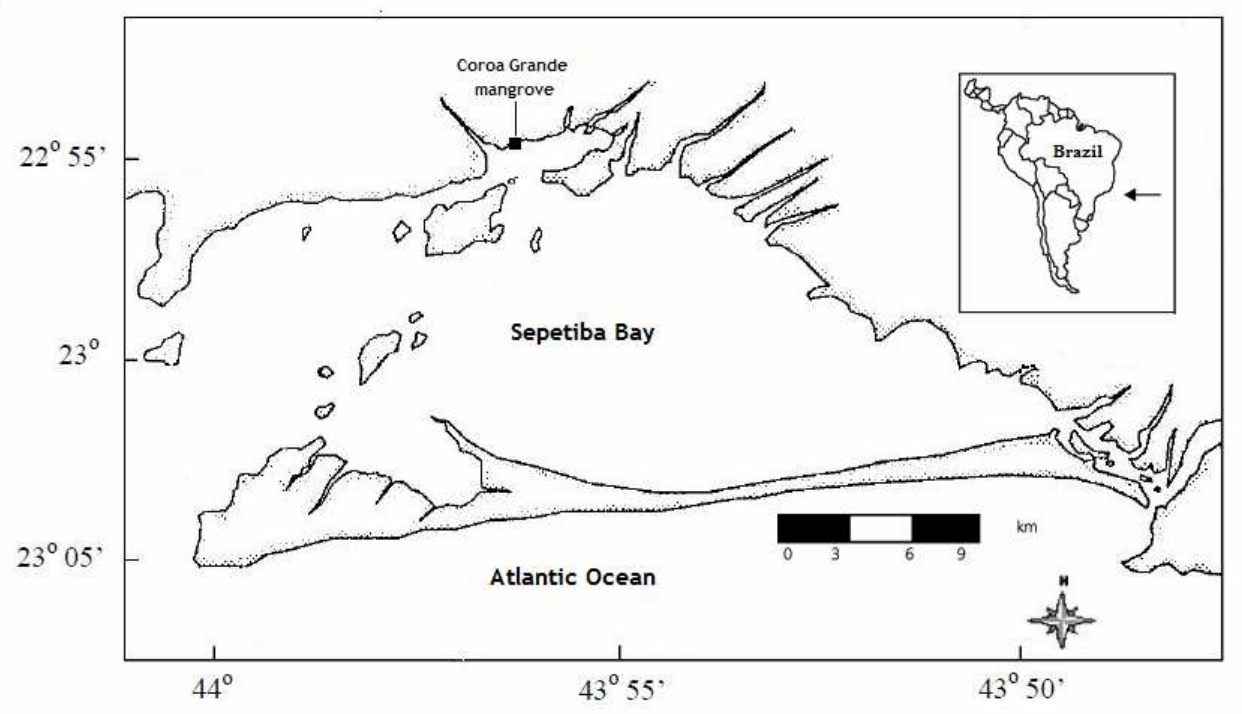

Fig. 1. Study area: Coroa Grande mangrove swamp, Sepetiba Bay, Rio de Janeiro ( $\bullet$. 
Aliquots of each homogenised dried sample were digested in $5 \mathrm{~mL}$ of $14 \mathrm{~N}$ nitric acid at $60^{\circ} \mathrm{C}$ on a hot plate until the solution became clear. After evaporation, the residue was dissolved in $10 \mathrm{~mL}$ of 0.3 $\mathrm{N}$ nitric acid.

Inductively coupled plasma atomic emission spectrometry (ICP-AES) was used for the determination of chromium, copper, nickel, lead, zinc, and cadmium; with the advantage of determining multi-elements in larger amounts, and traces without any change in experimental parameters. The following absorption lines were used: $\mathrm{Cr} 267.716 \mathrm{~nm} ; \mathrm{Cu}$ $324.754 \mathrm{~nm}$; Ni $231.604 \mathrm{~nm} ; \mathrm{Pb} 220.353 \mathrm{~nm} ; \mathrm{Zn}$ $213.856 \mathrm{~nm}$; and $\mathrm{Cd} 226.502 \mathrm{~nm}$. Accuracy and reproducibility of the methods were tested using muscle (Dorm-2, National Research Council, Canada) certified material. Standards and blanks were analysed along with each set of samples. Concentrations are expressed as $\mu \mathrm{g} \cdot \mathrm{g}^{-1}$ wet weight (wet weight- wwt).

Statistical analysis was undertaken using an Origin 7.5 software package (OriginLab Corporation) The average distribution of the heavy metals throughout the tissues of E. caerulea was assessed
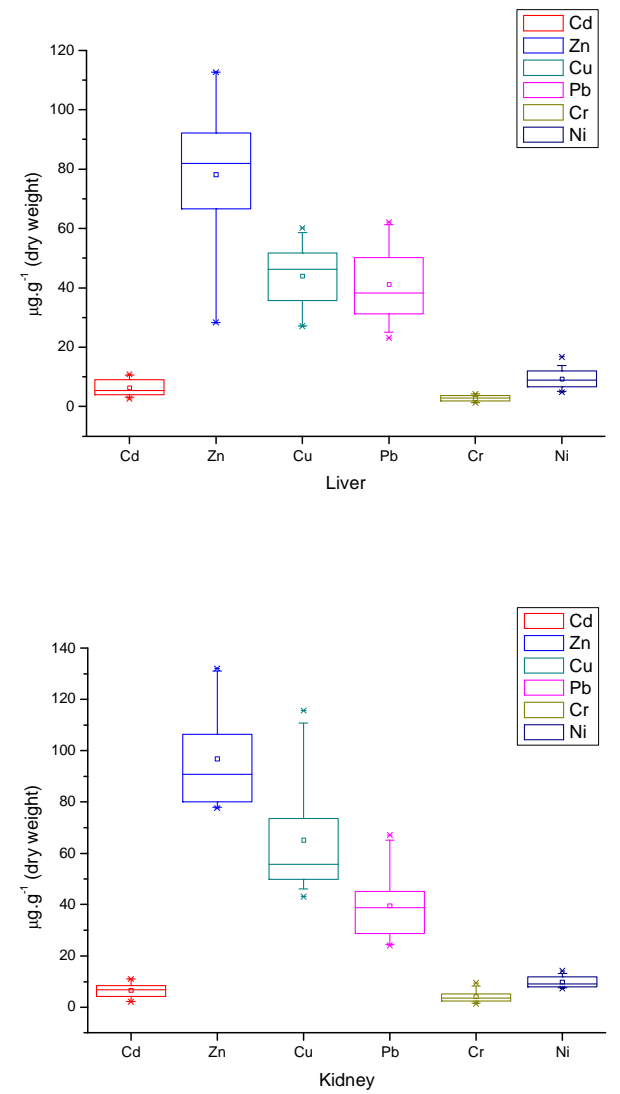

using analysis of variance (ANOVA), testing mean inter and intragroup differences between organs. In order to determine which organ was significantly different from the other, a post-hoc comparison was carried out using Tukey`s multiple comparison test. For all the tests, $p$-values of $<0.05$ were used to determine significant differences.

\section{RESUlts AND Discussion}

Concentrations of the elements analyzed in the livers and kidneys of adult E. caerulea are presented in Figure 2 and Table 1.

Mean concentration levels in the liver were $6.32955(2.63$ - 10.87)(Cd); $78.17409(28.3-$ 112.71)(Zn); $44.01727(27.1-60.17)(\mathrm{Cu}) ; 41.15091$ $(23.17-62.12)(\mathrm{Pb}) ; 2.80091(1.22-4.33)(\mathrm{Cr})$; and $9.27182(4.79-11.95)(\mathrm{Ni})$. Mean concentration levels in the kidney were $6.57136(2.15-11.09)(\mathrm{Cd})$; 96.89409 (77.7 - 132.1)(Zn); 65.20864 (43.11 $115.7)(\mathrm{Cu}) ; 39.62318(24.1-67.15)(\mathrm{Pb}) ; 4.16455$ $(1.34-9.44)(\mathrm{Cr})$; and $9.91091(7.23-14.15)(\mathrm{Ni})$.

Fig. 2. Cadmium $(\mathrm{Cd})$, zinc $(\mathrm{Zn})$, copper $(\mathrm{Cu})$, lead $(\mathrm{Pb})$, chromium $(\mathrm{Cr})$ and nickel $(\mathrm{Ni})$ concentrations $\left(\mu \mathrm{g} . \mathrm{gww}^{-1}\right.$ metal) in liver and kidney of Egretta caerulea. Box-plots illustrate the $10 \%, 25 \%, 50 \%$ (median), $75 \%$ and $90 \%$ percentiles and the outliers $(*)$. 
Table 1. Concentrations of elements analyzed $\left(\mu \mathrm{g} \cdot \mathrm{gww}^{-1}\right.$ metal) in livers and kidneys of E. caerulea $(\mathrm{n}=22)$.

\begin{tabular}{|c|c|c|c|c|c|c|c|c|c|c|}
\hline \multirow[t]{2}{*}{ Element } & \multicolumn{10}{|c|}{ Liver $\left(\mu g . g w w^{-1}\right)$} \\
\hline & Mean & $\operatorname{sd}(\mathbf{y E r} \pm)$ & $\operatorname{se}(\mathbf{y E r} \pm)$ & $\mathbf{P 2 5}$ & P75 & P95 & Min & Max & Range & Median \\
\hline Cd & 6.32955 & 2.65676 & 0.6642 & 4.04 & 9.01 & 10.58 & 2.63 & 10.87 & 8.24 & 5.95 \\
\hline $\mathbf{Z n}$ & 78.17409 & 23.6278 & 5.03746 & 66.65 & 92.15 & 112.7 & 28.3 & 112.71 & 84.41 & 82.8 \\
\hline $\mathbf{C u}$ & 44.01727 & 10.42818 & 2.22329 & 35.73 & 51.74 & 58.59 & 27.1 & 60.17 & 33.07 & 46.415 \\
\hline $\mathbf{P b}$ & 41.15091 & 12.31526 & 2.62562 & 31.17 & 50.14 & 61.24 & 23.17 & 62.12 & 38.95 & 38.745 \\
\hline $\mathrm{Cr}$ & 2.80091 & 1.02228 & 0.21795 & 1.86 & 3.67 & 4.21 & 1.22 & 4.33 & 3.11 & 2.955 \\
\hline $\mathbf{N i}$ & 9.27182 & 3.20751 & 0.68384 & 6.64 & 12.01 & 13.89 & 4.79 & 16.74 & 11.95 & 9.01 \\
\hline \multirow[t]{2}{*}{ Element } & \multicolumn{10}{|c|}{ Kidney $\left(\mu \mathrm{g} . \mathrm{gww}^{-1}\right)$} \\
\hline & Mean & $\operatorname{sd}(\mathbf{y E r} \pm)$ & $\operatorname{se}(\mathbf{y E r} \pm)$ & P25 & P75 & P95 & Min & Max & Range & Median \\
\hline Cd & 6.57136 & 2.62989 & 0.56069 & 4.25 & 8.39 & 11.02 & 2.15 & 11.09 & 8.94 & 6.885 \\
\hline Zn & 96.89409 & 18.41633 & 3.92637 & 80.07 & 106.45 & 131.11 & 77.7 & 132.1 & 54.4 & 92.315 \\
\hline $\mathrm{Cu}$ & 65.20864 & 21.92692 & 4.67484 & 49.87 & 73.62 & 110.78 & 43.11 & 115.7 & 72.59 & 56.22 \\
\hline $\mathbf{P b}$ & 39.62318 & 12.60071 & 2.68648 & 28.7 & 45.2 & 65.1 & 24.1 & 67.15 & 43.05 & 38.96 \\
\hline $\mathrm{Cr}$ & 4.16455 & 2.30925 & 0.49233 & 2.34 & 5.19 & 8.15 & 1.34 & 9.44 & 8.1 & 3.615 \\
\hline $\mathbf{N i}$ & 9.91091 & 2.09964 & 0.44764 & 7.92 & 11.87 & 13.13 & 7.23 & 14.15 & 6.92 & 9.155 \\
\hline
\end{tabular}

According to the ANOVA test, significant differences $(\mathrm{P}=0.05)$ were found for all metals in the liver $(\mathrm{F}=137.84771 ; \mathrm{P}=0)$, and in the kidney $(\mathrm{F}=$ $189.04542 ; \mathrm{P}=0)$. In the individual analysis for each metal in liver and kidney, three of them presented no significant differences: $\mathrm{Cd}(\mathrm{F}=0.09206 ; \mathrm{P}=0.76308)$ $\mathrm{Pb}(\mathrm{F}=0.16540 ; \mathrm{P}=0.68630)$, and $\mathrm{Ni}(\mathrm{F}=0.45813 ; \mathrm{P}=$ 0.50221). The other three presented significant differences: $\quad \mathrm{ZN} \quad(\mathrm{F}=8.59076 ; \quad \mathrm{P}=0.00545), \quad \mathrm{Cu}$ $(\mathrm{F}=16.75829 ; \mathrm{P}=0.00019)$, and $\mathrm{Cr}(\mathrm{F}=6.41439 ; \mathrm{P}=$ 0.01514 )

The comparison of the means using Tukey's Test indicated that in the liver $(\mathrm{P}=0.05), \mathrm{Cd}$ concentrations did not differ significantly for $\mathrm{Pb}$ and $\mathrm{Cr}$, but did differ significantly for $\mathrm{Zn}$, and $\mathrm{Cu}$; $\mathrm{Zn}$ concentrations differed significantly for $\mathrm{Cu}, \mathrm{Pb}, \mathrm{Cr}$, and $\mathrm{Ni}$; $\mathrm{Cu}$ concentrations did not differ significantly for $\mathrm{Pb}$, but differed significantly for $\mathrm{Cr}$ and $\mathrm{Ni} ; \mathrm{Pb}$ concentrations differed significantly for $\mathrm{Cr}$ and $\mathrm{Ni} ; \mathrm{Cr}$ concentrations did not differ significantly for $\mathrm{Ni}$.

The comparison of the means using the Tukey Test indicated that in the kidney $(\mathrm{P}=0.05), \mathrm{Cd}$ concentrations did not differ significantly for $\mathrm{Cr}$ and $\mathrm{Ni}$, but did differ significantly for $\mathrm{Zn}$, and $\mathrm{Pb} ; \mathrm{Zn}$ concentrations differed significantly for $\mathrm{Cu}, \mathrm{Pb}, \mathrm{Cr}$, and $\mathrm{Ni}$; $\mathrm{Cu}$ concentrations differed significantly for $\mathrm{Pb}, \mathrm{Cr}$, and $\mathrm{Ni} ; \mathrm{Pb}$ concentrations differed significantly for $\mathrm{Cr}$ and $\mathrm{Ni}$; $\mathrm{Cr}$ concentrations did not differ significantly for $\mathrm{Ni}$.

Examination of metal uptake and accumulation in E. caerulea inhabiting the site provided useful information about metal availability, uptake, and distribution that can be used for health effect assessments to determine risk and the effects of such exposures. There are few data available on the levels of metals in birds in Sepetiba Bay. Most of the research has focused on fish, a fact that initially guided the selection of metals to be included in this study. Data show worrying levels of some metals in many fish species and the same levels were expected in the samples analyzed in this study.

The levels of $\mathrm{Cd}, \mathrm{Zn}, \mathrm{Pb}$, and $\mathrm{Cu}$ found in seabirds are the result of two main processes: bioaccumulation through food and biodegradation by environmental processes (JOHANSEN et al., 2006). According to Schmitt-Jansen et al. (2008), the sublethal effects on birds include growth retardation, suppression of egg production, thinner egg shells and changes in behavior.

Cadmium is known for its long half-life in biological systems (decades in humans and years in birds), and $0.1-1.0 \%$ of ingested $\mathrm{Cd}$ is absorbed through the avian gastrointestinal tract to be distributed to kidney and liver. The high levels of $\mathrm{Cd}$ detected in the kidneys are higher than had been expected, but on the other hand, as compared to that in the liver, may indicate high exposure (THOMPSON et al., 2007). The metallothionein are a group of soluble molecules of low molecular weight, characterized by their stability in high temperatures, high cysteine content and the absence of flavored amino acids. These proteins act in the transport and storage of elements. They also provide protection from the effects of certain toxic metals, sequestering them and 
decreasing the amount of free metal ions (BUSTAMANTE et al., 2008).

The levels of essential metals such as $\mathrm{Zn}$ in seabird tissues are regulated metabolically. Zn plays an important role in many metabolic processes, especially in the activation of enzymes and the regulation of gene expression (SAVINOV et al., 2003). Its higher concentration may, therefore, impair physiological functions in birds, as well as contributing to a decline in species populations. Levels of $\mathrm{Zn}$ were higher in both the kidney and the liver.

Lead absorption through the gastrointestinal tract ranges from 4-70\% depending on the form of $\mathrm{Pb}$ ingested and the age of the exposed individual. A large amount of lead is deposited in bone, which acts as a depot that provides a reliable indication of long-term exposure.

Heavy metals comprise a significant part of the pollutants in the marine environment. It is important to distinguish between the introduction of these metals from anthropogenic activities and those from natural weathering processes. Although sources of heavy metals in the marine environment are relatively diverse, in Sepetiba Bay there is strong evidence of these metals' widespread adverse biological effects on fish, their presence in seafood constituting a risk to human health (KAREZ et al., 1994). The known toxicity of some metals leads one to foresee problems due to their effects in terms of speciation and future research should be intensified.

At the present time there are unprecedented pressures on natural resources (LAUWERYS; HOET, 1993). Sustainable use of these resources is hindered by an inability to foresee emerging environmental problems at an early stage when remedial measures may still be effective. Nowhere is this inadequacy so pronounced as in the marine environment. Global energy cycles and the biological processes upon which all life depends are critically influenced by the ocean (PAIN et al., 1998; PEREIRA; EBECKEN, 2009).

The assessment of environmental variables and their biological effects in seabirds will provide critical insights into the level and extent of the effects in terms of public health associated with marine areas and resources. The direct contaminant loads and exposure will, further, assist regional, and consequently, national decision-makers in their efforts to ensure the sustained protection of marine ecosystems.

\section{ACKNOWLedGEMENTS}

I am grateful for the laboratorial support of the UFRRJ and FIOCRUZ, and for the financial support received from the Conselho Nacional de
Desenvolvimento Científico e Tecnológico - CNPq, bolsa de produtividade (306175/2008-8).

\section{REFERENCES}

AMADO- FILHO, G.M.; ANDRADE, L.R.; KAREZ, C.S.; FARINA, M.; PFEIFER, W.C. Brown algae species as biomonitors of $\mathrm{Zn}$ and $\mathrm{Cd}$ at Sepetiba Bay, Rio de Janeiro, Brazil. Mar. environ. Res., v. 48, p. 213-224, 1999.

BONCOMPAGNI, E.; MUHAMMAD, A.; JABEEN, R.; ORVINI, E.; GANDINI, C.; SANPERA, C.; RUIZ, X.; FASOLA, M. Egrets as monitors of trace-metal contamination in wetland of Pakistan. Archs environ. Contamin. Toxicol., v. 4, p. 399-406, 2003

BURGER, J.; GOCHFELD, M. 1993. Heavy metal and selenium levels in feathers of young egrets and Herons from Hong Kong and Szechuan, China. Archs environ. Contamin. Toxicol., v. 25, p. 322-327,1993.

BUSTAMANTE, P.; GONZÁLEZ, A. F; ROCHA, F; MIRAMAND, P.; GUERRA, A. Metal and metalloid concentrations in the giant squid Architeuthis dux from Iberian waters. Mar. environ. Res., v. 66, n. 2, p. 278287, 2008.

COPELAND, G.; MONTEIRO, T.; COUCH, S.; BORTHWICK, A. Water quality in Sepetiba Bay, Brazil. Mar. environ. Res., v. 55, p. 385-408, 2003.

COSSON, R.P.; AMIARD, J.; AMIARD-TRIQUET, C. Trace elements in Little Egrets and Flamingos of Camargue, France. Ecotoxicol. Environ. Safety, v. 15, p. $107-116,1988$.

COSTANZA, R.; FARLEY, J. Ecological economics of coastal disasters: Introduction to the special issue. Ecol.Econ., v. 63, n. 2-3, p. 249-253, 2007.

DITTMAR, T.; HERTKORN, N.; KATTNER, G.; LARA, R. J. Mangroves, a major source of dissolved organic carbon to the oceans. Global biogeochem. Cycles, v. 20, p. 10-12, 2006

FERREIRA, A. P. Avaliação das concentrações de metais pesados no sedimento, água e em Leucopternis lacernulata (gavião-pomba). Estudo de caso: Baía de Sepetiba, Rio de Janeiro. Gaia Scientia, v. 3, n. 2, p. 2331, 2009.

JAUNIAUX, T.; BROSENS, L.; MEIRE, P.; OFFRINGA, H.; COIGNOUL, F. Pathological investigations on guillemots (Uria aalge) stranded at the Belgian coast during the winter 1993-1994. Veterin. Rec., v. 143, n. 14, p. 387-390, 1998

JOHANSEN, P.; MULVAD, G.; PEDERSEN, H. S.; HANSEN, J. C.; RIGET, F. Accumulation of cadmium in livers and kidneys in Greenlanders. Sci. total Environment, v. 372, n. 1, p. 58-63, 2006.

JURESA, D.; BLANUSA, M. Mercury, arsenic, lead and cadmium in fish and shellfish from the Adriatic Sea. Food Addit. Contamin., v. 20, p. 241-246, 2003.

KAREZ, C. S.; MAGALHÃES, V. F.; PFEIFFER, W. C. Trace metal accumulation by algae in Sepetiba Bay, Brazil. Environ. Pollut., v. 83, p. 351-356, 1994.

LACERDA, L. D.; MOLISANI, M. M. Three decades of Cd and $\mathrm{Zn}$ contamination in Sepetiba Bay, SE Brazil: Evidence from the mangrove oyster Crassostraea rhizophorae. Mar. Pollut. Bull., v. 52, n. 8, p. 974-977, 2006. 
LAUWERYS, R.; HOET, P. 1993. Industrial chemical exposure .Guidelines for biological monitoring. 2nd ed. Boca Raton, Fla.: Lewis Publishers, 1993

PAIN, D.J ; SÁNCHEZ, A.; MEHARG, A. A. The Doñana ecological disaster: contamination of a world heritage estuarine marsh ecosystem with acidified pyrite mine waste. Sci. total Environment, v. 222, p. 45-54, 1989.

PEREIRA, G. C.; EBECKEN, N. F. F. Knowledge discovering for coastal waters classification. Expert Systems with Applications, v. 36, n. 4, p. 8604 - 8609, 2009.

SAVINOV, V. M.; GABRIELSENB, G.W.; TATIANA, N.; SAVINOVA, T. N. Persistent organic pollutants and heavy metal contamination in the Russian arctic marine and freshwater environment. Sci. total Environment, v. 306, n. 1-3, p. 133-158, 2003.

SCHMITT-JANSEN, M.; VEIT, U.; DUDEL, G.; ALTENBURGER, R. An ecological perspective in aquatic ecotoxicology: Approaches and challenges. Basic appl. Ecol., v. 9, n. 4, p. 337-345, 2008.

STORELLI, M. M.; PERRONE, V. G.; MARCOTRIGIANO, G.O. Organochlorine contamination (PCBs and DDTs) in deep-sea fish from the Mediterranean sea. Mar. Pollut. Bull., v. 54, n. 12, p. 1968-1971, 2007.
THOMPSON, B.; ADELSBACH, T.; BROWN, C.; HUNT, J.; KUWABARA, J.; NEALE, J.; OHLENDORF, H.; SCHWARZBACH, S.; SPIES, R.; TABERSKI, K. 2007. Biological effects of anthropogenic contaminants in the San Francisco Estuary. Environ. Res., v. 105, n. 1,p. 156-174, 2007.

TOMAN, R.; MASSÁNYI, P.; LUKÁČ, N.; DUCSAY, L.; GOLIAN, J. 2005. Fertility and content of cadmium in pheasant (Phasianus colchicus) following cadmium intake in drinking water. Ecotoxicol. environ. Safety, v. 62, n. 1, p. 112-117, 2005.

WALSH, P.M. The use of seabirds as monitors of heavy metals in the marine environment. Boca Raton, Fla: CRC Press, 1990.

(Manuscript received 01 July 2009; revised 27 October 2009; accepted 20 May 2010) 